\title{
Bioengineered vascular grafts: So close and yet so far
}

\author{
Robert B. Cameron, MD
}

\footnotetext{
From the Division of Thoracic Surgery, Department of Surgery, David Geffen School of Medicine at UCLA, Los Angeles, Calif; and Division of Thoracic Surgery, Department of Surgery and Perioperative Care, West Los Angeles VA Medical Center, Los Angeles, Calif.

Disclosures: Author has nothing to disclose with regard to commercial support.

Received for publication June 10, 2018; revisions received June 10, 2018; accepted for publication June 12, 2018; available ahead of print Aug 2, 2018

Address for reprints: Robert B. Cameron, MD, Division of Thoracic Surgery, Department of Surgery, David Geffen School of Medicine, 10780 Santa Monica Blvd, Suite 100, Los Angeles, CA 90025 (E-mail: rcameron@stanfordalumni.org).

J Thorac Cardiovasc Surg 2018;156:1823-4

$0022-5223 / \$ 36.00$

Copyright (C) 2018 by The American Association for Thoracic Surgery

https://doi.org/10.1016/j.jtcvs.2018.06.042
}

Vascular disease, including coronary artery, peripheral vascular, and cerebrovascular disease, remains a huge source of morbidity and mortality worldwide, despite improvements in risk factor mitigation. The mainstay of surgical palliation of vascular disease is the surgical bypass graft-a "device" that is used more than 1 million times annually in the United States during an estimated 400,000 coronary bypass procedures alone. ${ }^{1}$ Worldwide, the annual number of vascular grafts, including peripheral vascular and dialysis access, likely exceeds 3 to 4 million. Bypass conduits primarily consist of autologous artery/vein, artificial material (ie, polytetrafluoroethylene), or rarely cryopreserved allografts. Problems with all of these conduits, such as availability and suitability, exist, particularly for small-diameter grafts, and these deficiencies have fueled a long-standing search for the ideal bypass conduit that is immediately available in appropriate sizes, is biologic, and provides nearly perfect long-term patency rates.
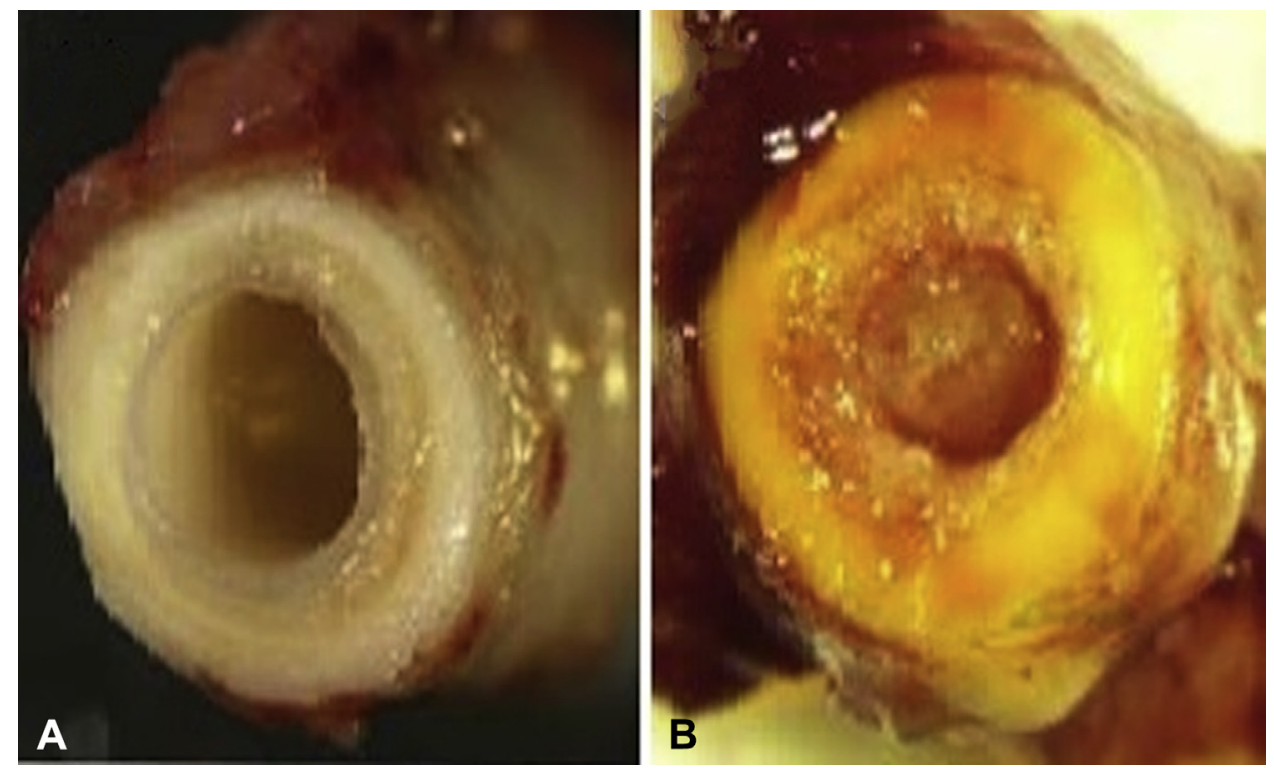

FIGURE 1. Patent (A) and occluded (B) grafts from human bioengineered bilayered poly(ester urethane)urea Lewis rat aortic interposition grafts. Reprinted with permission. ${ }^{2}$ 
difficult to achieve. Haskett and colleagues ${ }^{2}$ report a potentially significant enhancement to their previous technique of bioengineered conduit construction, which required 48 hours of "dynamic" culture. The updated protocol eliminates any culture time, thereby allowing fresh human stromal vascular fraction cells to be seeded immediately onto $1.3-\mathrm{mm}$ bilayered poly(ester urethane) urea. The resulting conduits were implanted as interposition grafts into the abdominal aorta of Lewis rats, recovered 8 weeks later, and assessed for patency and evidence of tissue healing and remodeling. Patency was maintained in 5 of 7 animals after 8 weeks, which is reasonable for this xenograft model, but the 2 occluded grafts had significant anastomotic intimal hyperplasia (Figure 1).

Advantages of eliminating any culture period in conduit preparation cannot be overemphasized because culture requirements are associated with issues from sterility to clinical care issues, logistics, and probably most daunting, cost. Similar culture requirements for chimeric antigen receptor T-cell therapy now used in the treatment of acute lymphoblastic leukemia and large B-cell lymphoma comes with a price tag of $\$ 475,000$ for a single treatment. ${ }^{3}$ Although improved, the updated technique of Haskett and colleagues $^{2}$ still requires further refinement because the described manual tissue processing hardly lends itself to adoption in a large-scale manufacturing context.
Fortunately, similar results likely can be achieved using automated commercial cell harvesting systems that are currently available in Europe (CE Mark) and China. ${ }^{4}$ However, the biggest hurdle remains the translation of these findings into daily clinical practice. Although some early clinical trials with bioengineered vascular conduits already have reported encouraging results, long-term patency remains a challenge. ${ }^{5}$ Therefore, despite clear but slow progress toward bioengineered bypass grafts, do not discard your endoscopic vessel harvesting systems just yet-they are going to be necessary for the foreseeable future.

\section{References}

1. Alexander JH, Smith PK. Coronary-artery bypass grafting. N Engl J Med. 2016; 375:e22.

2. Haskett DG, Saleh KS, Lorentz KL, Josowitz AD, Luketich SK, Weinbaum JS, et al. An exploratory study on the preparation and evaluation of a "same-day" adipose stem cell-based tissue-engineered vascular graft. J Thorac Cardiovasc Surg. 2018;156:1814-22.

3. Caffrey M. With approval of CAR T-cell therapy comes the next challenge: payer coverage. Am J Managed Care. 2018;24:35-6.

4. Duckers HJ, Pinkernell K, Milstein AM, Hedrick MH. The Bedside Celution ${ }^{\text {TM }}$ system for isolation of adipose derived regenerative cells. EuroIntervention. 2006;2:395-8.

5. Lawson JH, Glickman MH, Ilzecki M, Jakimowicz T, Jaroszynski A, Peden EK, et al. Bioengineered human acellular vessels for dialysis access in patients with end-stage renal disease: two phase 2 single-arm trials. Lancet. 2016;387: 2026-34. 